\title{
KEPATUHAN MENJALANI TERAPI HEMODIALISA DENGAN KUALITAS HIDUP PASIEN GAGAL GINJAL KRONIK
}

\author{
I Nengah Nuarta Jaya ${ }^{1}$ I Made Dwie Pradnya Susila, , Gede Arya Bagus Arisudhana \\ STIKES Bina Usada Bali ${ }^{1}$ \\ e-mail: dwiepradnya@gmail.com*
}

\begin{abstract}
Chronic renal failure is a condition of decreased kidney function gradually or overall and requires kidney replacement therapy to maintain life. Hemodialysis is a therapy for patients with chronic renal failure. Compliance with hemodialysis therapy is one of the important things to note, if the patient is not compliant it can cause a buildup of harmful substances in the body that will have an impact on the quality of life of the patient. This study aimed to analyze the correlation between compliance undergoing hemodialysis therapy and life quality of patients with chronic renal failure in the hemodialysis ward of Tabanan Regional Hospital. This study was quantitative by using a descriptive correlational design method with cross sectional approach. The population in this study was chronic renal failure patients who underwent hemodialysis in the hemodialysis ward of Tabanan Regional Hospital. as many as 260 respondents. The sampling technique was by using nonprobability sampling technique with purposive sampling technique with a total sample of 72 respondents. Data collection used questionnaire sheets. Lambda test results obtained $p$-value $=0.005$ ( $p<0.05)$ then HO was rejected, which means that there was a correlation between compliance undergoing hemodialysis therapy and life quality of patients with chronic renal failure in the hemodialysis ward of Tabanan Regional Hospital. The closeness of the correlation between variables can be seen from $r$-alue $=0.238$ which had a weak correlation.
\end{abstract}

Keywords: Chronic Renal Failure, Hemodialysis, Compliance, Quality of Life

\begin{abstract}
ABSTRAK
Gagal ginjal kronik (GGK) merupakan suatu kondisi menurunnya fungsi ginjal secara bertahap ataupun keseluruhan dan membutuhkan terapi pengganti ginjal untuk mempertahankan hidup. Hemodialisa merupakan salah satu terapi untuk penderita GGK. Kepatuhan menjalani terapi hemodialisa merupakan salah satu hal yang penting untuk diperhatikan, jika pasien tidak patuh dapat menyebabkan penumpukan zat-zat berbahaya dalam tubuh yang akan berdampak terhadap kualitas hidup pasien. Penelitian ini bertujuan untuk menganalisa hubungan antara kepatuhan menjalani terapi hemodialisa dengan kualitas hidup pasien gagal ginjal kronik di ruang hemodialisa BRSUD Tabanan. Jenis penelitian yaitu kuantitatif dengan menggunakan metode desain deskriptif korelasi dengan pendekatan cross sectional. Populasi dalam penelitian ini adalah pasien gagal ginjal kronik yang menjalani hemodialisa di ruang hemodialisa BRSUD Tabanan sebanyak 260 responden. Teknik pengambilan sampel yaitu menggunakan teknik non-probability sampling dengan teknik purposive sampling dengan jumlah sampel sebanyak 72 responden. Pengumpulan data menggunakan lembaran kuesioner. Hasil uji Lambda didapatkan hasil nilai $\mathrm{p}=0,005(\mathrm{p}<0,05)$ maka $\mathrm{H} 0$ ditolak yang berarti terdapat hubungan antara kepatuhan menjalani terapi hemodialisa dengan kualitas hidup pasien gagal ginjal kronik di ruang hemodialisa BRSUD Tabanan. Keeratan hubungan antara variabel dapat dilihat dari nilai $\mathrm{r}=0,238$ yang memiliki korelasi lemah.
\end{abstract}

Kata kunci: Gagal Ginjal Kronik, Hemodialisa, Kepatuhan, Kualitas Hidup

\section{PENDAHULUAN}

Gagal Ginjal Kronis (GGK) menjadi masalah kesehatan global dengan angka kejadian gagal ginjal yang terus meningkat. Saat ini GGK semakin banyak menarik perhatian dan banyak dipelajari karena walaupun sudah mencapai tahap terminal penderita masih dapat hidup dengan kualitas yang cukup baik (Rustandi, 2018). Gagal Ginjal Kronik adalah suatu kerusakan pada struktur atau fungsi ginjal yang berlangsung $\geq 3$ bulan, dengan atau tanpa penurunan glomerular filtration rate (GFR) (National Kidney Foundation, 2016).

Data dari World Health Organization (WHO) tahun 2018, GGK telah menjadi masalah kesehatan serius di dunia. Penyakit ginjal telah menyebabkan kematian sebesar 850.000 orang setiap tahunnya. Hal ini menunjukan bahwa penyakit ini menjadi penyebab 
kematian ke-12 tertinggi di dunia. Di Indonesia GGK mengalami peningkatan dari tahun 2013 yaitu 0,2\% naik menjadi $0,38 \%$ pada tahun 2018. Sejalan dengan data nasional di Provinsi Bali juga mengalami peningkatan penderita GGK adalah $0,44 \%$ atau berjumlah 12.092 pasien (Kementerian Kesehatan Republik Indonesia, 2018). Kasus GGK tertinggi di Provinsi Bali terdapat di Kabupaten Karangasem yaitu 0,4\% diikuti oleh Kabupaten Buleleng yaitu 0,3\% dan di Kabupaten Tabanan sendiri terdapat 0,1\% pasien dengan GGK (Kementerian Kesehatan Republik Indonesia, 2013).

Saat ini terdapat 3 terapi modalitas pengobatan yang tersedia untuk gagal ginjal kronik yaitu hemodialisa, peritoneal dialisis dan transplantasi ginjal (Aryzki, 2019). Hemodialisa merupakan terapi cuci darah yang paling banyak dilakukan, yang dilakukan 2-3 kali seminggu dengan lama waktu 4-5 jam, yang bertujuan untuk mengeluarkan sisa-sisa metabolisme protein dan mengoreksi gangguan keseimbangan cairan dan elektrolit (Siahaan, 2018).

Pasien GGK yang melakukan hemodialisa di dunia diperkirakan 1,5 juta orang dengan insiden pertumbuhan $8 \%$ pertahun (World Health Organization, 2015). Di Indonesia pesien GGK yang menjalani hemodialisa terjadi peningkatan dari tahun 2017 sebanyak 30.831 pasien baru dan 77.892 pasien aktif, di tahun 2018 sebanyak 66.433 pasien baru dan 13.2142 pasien aktif yang menjalani hemodialisa. Di Bali jumlah pasien yang menjalani hemodialisa sebanyak 2.748 pasien baru yang menjalani hemodialisa (Indonesia Renal Registry, 2018).

Pasien yang menjalani hemodialisa mengalami berbagai masalah yang timbul akibat tidak berfungsinya ginjal. Permasalahan fisiologis yang sering dialami oleh pasien hemodialisa yaitu jantung berdebar, berkeringat, sesak nafas, gangguan tidur, kelelahan, gatal-gatal, kram otot, sering kencing, sakit kepala, penglihatan kabur, pusing, mual, muntah, kurang nafsu makan, kulit kering, nyeri tulang/sendi. Selain permasalahan fisiologis, pasien juga mengalami permasalahan psikologis antara lain kecemasan, depresi, isolasi sosial, kesepian, tidak berdaya dan putus asa (Nurlinawati, 2019).

Terapi hemodialisa tidak dapat menyembuhkan penyakit atau memulihkan keadaan pasien seperti semula, pasien harus menjalani dialisis sepanjang hidupnya atau sampai mendapat ginjal baru melalui operasi pencangkokan ginjal sehingga menyebabakan pasien harus patuh menjalani terapi hemodialisa (Puspasari, 2018). Kepatuhan penderita GGK dalam menjalani program terapi hemodialisa merupakan hal yang penting untuk diperhatikan. Apabila pasien tidak patuh dalam menjalani terapi hemodialisa, akan terjadi penumpukan zat-zat berbahaya dari tubuh hasil metabolisme dalam darah sehingga penderita akan merasa sakit seluruh tubuh dan jika hal tersebut dibiarkan maka akan menimbulkan kematian (Kusniawati, 2018). Oleh karena itu, pasien gagal ginjal harus patuh dalam menjalani terapi hemodialisa sesuai jadwal yang telah ditetapkan.

Kepatuhan diartikan sebagai tingkatan perilaku seseorang yang mendapatkan pengobatan, mengikuti diet, dan atau melaksanakan perubahan gaya hidup sesuai dengan rekomendasi pemberi pelayanan kesehatan (Manguma, 2014). Jika pasien GGK tidak patuh melakukan hemodialisa dapat memberikan dampak negatif yang luar biasa. Hal ini menyebabkan angka mortalitas dan morbiditas pasien GGK akan menjadi semakin tinggi lagi (Hutagaol, 2017). Berdasarkan hasil penelitian Anggraini (2017), terdapat hubungan antara kepatuhan kemoterapi dengan kualitas hidup pasien kanker serviks di Rumah Sakit Dr. Moewardi. Pasien diharapkan untuk mematuhi terapi hemodialisa agar tercapai kualitas hidup yang baik.

Kualitas hidup seseorang tidak dapat didefinisikan dengan pasti, hanya orang tersebut yang dapat mendefinisikannya, karena kualitas hidup merupakan suatu yang bersifat subyektif. World Health Organization Quality of Life(WHOQoL) menyatakan kualitas hidup adalah persepsi individu dalam kemampuan, keterbatasan, gejala serta sifat psikososial hidupnya dalam konteks budaya dan sistem nilai untuk menjalankan peran dan fungsinya (World Health Organization, 2016). Kualitas hidup dipengaruhi oleh beberapa faktor yaitu bagian pertama adalah sosio demografi meliputi jenis kelamin, usia, suku/etnik, pendidikan, pekerjaan dan status perkawinan. Bagian kedua adalah medik berupa lama menjalani hemodialisa, stadium penyakit, dan terapi yang dijalani (Rahman, Kaunang, \& Elim, 2016). Penilaian terhadap kualitas hidup merupakan faktor yang penting. Kualitas hidup merupakan indikator digunakan untuk menilai keefektifan tindakan hemodialisa yang diberikan, sehingga kualitas hidup juga menjadi tujuan penting dalam pengobatan penyakit ginjal tahap akhir.

Berdasarkan data di Ruang Hemodialisa Badan Rumah Sakit Umum Daerah (BRSUD) Tabanan pada tahun 2017 rata-rata jumalah pasien menjalani hemodialisa sebanyak 216 pasien/bulan, meningkat pada tahun 2018 menjadi 244 pasien/bulan, dan pada agustus tahun 2019 menjadi 260 pasien/bulan dibandingkan Rumah Sakit Umum Mangusada jumlah pasien yang menjalani hemodialisa pada tahun 2018 rata-rata sebanyak 130 orang/bulan meningkat pada bulan agustus 2019 sebanyak 145 pasien/bulan. Di Badan Rumah Sakit Umum Daerah (BRSUD) Tabanan terdapat 40 mesin dialisis dengan jadwal yang berlaku yaitu setiap pasien mendapatkan jadwal terapi hemodialisa 2 kali seminggu yaitu setiap hari senin dan kamis, selasa dan jumat, serta rabu dan sabtu dengan lama waktu 5 jam untuk satu kali tindakan hemodialisa.

Dari hasil observasi dan wawancara kepada 10 orang pasien selama peneliti melakukan studi pendahuluan di Ruang Hemodialisa BRSUD Tabanan. Hasil observasi memperlihatkan 8 orang pasien 
datang di antar dengan kondisi baik dan dapat berkomunikasi seperti biasa serta ditemani oleh keluarganya, 2 orang pasien datang sendiri tanpa ditemani oleh keluarga. Sedangkan dari hasil wawancara, 10 orang pasien mengatakan mengurangi aktivitas fisik karena kelemahan dan mudah lelah harus rutin menjalani hemodialisa $2 \mathrm{kali} / \mathrm{minggu}$. Berdasarkan hasil wawancara dengan kepala ruangan hemodialisa, beliau mengatakan bahwa pasien-pasien di ruang hemodialisa masih banyak yang tidak patuh dengan jadwal terapi yang sudah diberikan oleh dokter. Banyak pasien yang tidak menjalani cuci darah sehingga kondisinya memburuk karena adanya peningkatan ureum dan kreatinin yang mengakibatkan terjadi penumpukan racun didalam tubuh pasien, sehingga kondisi akan pasien memburuk.

\section{METODE}

Penelitian ini merupakan penelitian kuantitatif dengan menggunakan metode deskriptif korelasi dengan pendekatan cross sectional yaitu dimana variabel independen dan dependen diteliti secara bersamaan atau sekali waktu (Nursalam, 2017). Populasi dalam penelitian ini adalah semua penderita gagal ginjal kronik yang sedang menjalani terapi hemodialisa di BRSUD Tabanan satu bulan terakhir yaitu bulan agustus 2019 sebanyak 260 orang dengan sampel penelitian yang digunakan sebanyak 72 orang. Penentuan sampel penelitian ini menggunakan nonprobability sampling yaitu purposive sampling. Dengan kriteria inklusi: menjalani terapi hemodialisa, bersedia menjadi responden penelitian ini dengan menandatangani informed consent, tingkat kesadaran compos mentis, mampu berkomunikasi dengan bahasa lisan atau tulisan dan kriteria eksklusi: pasien hemodialisa yang menjalani rawat inap, pasien mengalami gangguan kesadaran. Instrumen dalam penelitian ini menggunakan kuesioner yang terdiri dari tiga bagian, yaitu karakteristik Responden berisi 6 buah pertanyaan (meliputi usia, jenis kelamin, pendidikan, status perkawinan, pekerjaan dan lama menjalani hemodialisa), kepatuhan menjalani hemodialisa menggunakan kuesioner The End-Stage Renal Disease Adherence Quistionnaire (ESRD-AQ) yang telah dimodifikasi oleh Syamsiah (2011), dan kualitas hidup menggunakan kuesioner WHOQOL (WorldHealth Organization Quality Of Life)-BREF. Penelitian ini telah memenuhi persyaratan etik penelitian sehingga mendapatkan keterangan kelaikan etik (ecthical approval) dari Komisi Etik Penelitian kesehatan STIKES Bina Usada Bali No. 511/EA/KEPK-BUB-2019. Analisa data dalam penelitian ini menggunakan Uji Lamda untuk mengetahui korelasi antara variabel independen dan dependen.

\section{HASIL}

Analisis Univariat

Tabel 1

Karakteristik Responden

\begin{tabular}{ccc}
\hline $\begin{array}{c}\text { Karakteristik } \\
\text { responden }\end{array}$ & $\begin{array}{c}\text { Frekuensi } \\
(\mathrm{n})\end{array}$ & $\begin{array}{c}\text { Persentase } \\
(\%)\end{array}$ \\
\hline Usia & 2 & 2,8 \\
$17-25$ tahun & 5 & 6,9 \\
26-35 tahun & 10 & 13,9 \\
36-45 tahun & 23 & 31,9 \\
46-55 tahun & 25 & 34,7 \\
56-65 tahun & 7 & 9,7 \\
65- ke atas & 72 & 100 \\
\hline Jumlah & & \\
Jenis & 41 & 56,9 \\
kelamin & 31 & 41,3 \\
Laki-laki & & \\
Perempuan & 72 & 100 \\
\hline Jumlah & & \\
Pendidikan & 4 & 5,6 \\
Tidak & 31 & 43,1 \\
Sekolah & 11 & 15,3 \\
SD & 16 & 22,2 \\
SLTP & 10 & 13,9 \\
SLTA & & \\
Perguruan & &
\end{tabular}

Tinggi

\begin{tabular}{cll}
\hline Jumlah & 72 & 100 \\
\hline $\begin{array}{c}\text { Status } \\
\text { Perkawinan } \\
\text { Lajang } \\
\text { Menikah }\end{array}$ & 5 & 6,9 \\
Jumlah & 72 & 93,1 \\
\hline Pekerjaan & & 100 \\
Tidak & 51 & 70,8 \\
bekerja & 1 & 1,4 \\
PNS & 1 & 1,4 \\
Swasta & 14 & 19,4 \\
Wiraswasta & 5 & 6,9 \\
IRT & & \\
\hline Jumlah & 72 & 100 \\
\hline Lama & & \\
Hemodialisa & 8 & 11,1 \\
$<6$ bulan & 64 & 88,9 \\
$>6$ bulan & & 100 \\
\hline Jumlah & 72 & \\
\hline
\end{tabular}

Berdasarkan tabel 1 diatas, dari 72 responden didapatkan paling banyak berusia 56-65 tahun yaitu sejumlah 25 responden $(34,7 \%)$ dan yang paling sedikit pada usia 17-25 tahun sebanyak 2 responden $(2,8 \%)$. Ditinjau dari jenis kelamin paling banyak 


\section{Vol. 15 No. 3 September - Desember 2020}

responden berjenis kelamin laki-laki yaitu sebanyak 41 responden $(56,9 \%)$ dan responden perempuan sebanyak 31 responden $(41,3 \%)$. Ditinjau dari pendidikan paling banyak responden tingkat pendidikan SD yaitu sebanyak 31 responden $(43,1 \%)$ dan paling sedikit tidak sekolah yaitu sebanyak 4 responden (5,6\%). Ditinjau dari status perkawinan paling banyak responden yang sudah menikah yaitu sebanyak 67 responden $(93,1 \%)$ dan responden yang lajang yaitu sebanyak 5 responden $(6,9 \%)$. Ditinjau dari pekerjaan paling banyak responden tidak bekerja yaitu sebanyak 51 responden $(70,8 \%)$ dan paling sedikit bekerja sebagai PNS dan swasta yaitu sebanyak 1 responden (1,4\%). Ditinjau dari lama menjalani hemodialisa bahwa paling banyak responden sudah $>6$ bulan menjalani hemodialisa yaitu sebanyak 64 responden $(88,9 \%)$ dan responden yang $<6$ bulan yaitu sebanyak 8 responden $(11,1 \%)$.

Tabel 2

Kepatuhan Menjalani Terapi Hemodialisa.

\begin{tabular}{lll}
\hline Kepatuhan & Frekuensi (n) & $\begin{array}{l}\text { Persentase } \\
(\%)\end{array}$ \\
\hline Tidak patuh & 24 & 33,3 \\
Patuh & 48 & 66,7 \\
\hline Jumlah & 72 & 100 \\
\hline
\end{tabular}

Berdasarkan tabel 2 diatas, dari 72 responden didapatkan bahwa paling banyak responden patuh menjalani terapi hemodialisa yaitu sebanyak 48 responden $(66,7 \%)$ dan yang tidak patuh sebanyak 24 responden $(33,3 \%)$.

Tabel 3

Kualitas Hidup Pasien Gagal Ginjal Kronik.

\begin{tabular}{lll}
\hline Kualitas Hidup & $\begin{array}{l}\text { Frekuensi } \\
\text { (n) }\end{array}$ & $\begin{array}{l}\text { Persenta } \\
\text { se (\%) }\end{array}$ \\
\hline Kualitas hidup buruk & 16 & 22,2 \\
Kualitas hidup & 26 & 36,1 \\
sedang & 30 & 41,7 \\
Kualitas hidup baik & & \\
\hline Jumlah & 72 & 100 \\
\hline
\end{tabular}

Berdasarkan tabel 3 diatas, dari 72 responden didapatkan bahwa paling banyak responden memiliki kualitas hidup baik yaitu sebanyak 30 responden $(41,7 \%)$ dan yang paling sedikit memiliki kualitas hidup buruk sebanyak 16 responden $(22,2 \%)$.

\author{
Analisa Bivariat \\ Hubungan Antara Kepatuhan Menjalani Terapi \\ Hemodialisa Dengan Kualitas Hidup Pasien Gagal \\ Ginjal Kronik Di Ruang Hemodialisa BRSUD \\ Tabanan
}

Hasil penelitian didapatkan bahwa responden yang tidak patuh paling banyak memiliki kualitas hidup buruk sebanyak 12 responden $(16,7 \%)$ dan paling sedikit memiliki kualitas hidup baik sebanyak 2 responden $(2,8 \%)$, sedangkan responden yang patuh paling banyak memiliki kualitas hidup yang baik sebanyak 28 responden $(38,9 \%)$ dan paling sedikit memiliki kualitas hidup yang buruk sebanyak 4 responden $(5,6 \%)$.

Hasil analisis bivariat menggunakan uji Lambda diperoleh nilai $\mathrm{p}=0,005$ karena nilai $\mathrm{p}<\alpha(0,05)$, maka $\mathrm{H} 0$ ditolak. Hal ini berarti bahwa ada hubungan yang bermakna antara kepatuhan menjalani terapi hemodialisa dengan kualitas hidup pasien gagal ginjal kronik di ruang hemodialisa BRSUD Tabanan. Kuat lemahnya korelasi dilihat dari nilai $r$ yaitu 0,238 yang menunjukkan korelasi lemah antara kepatuhan menjalani terapi hemodilisa dengan kualitas hidup pasien gagal ginjal.

\section{PEMBAHASAN}

Pembahasan akan menguraikan semua variabel dalam penelitian ini yang meliputi karakteristik responden (usia, jenis kelamin, tingkat pendidikan, pekerjaan, status pernikahan, lama menjalani hemodialisa), kepatuhan menjalani hemodialisa, kualitas hidup, dan hubungan kepatuhan menjalani hemodialisa dengan kualitas hidup.

\section{Karakteristik Responden}

a. Karakteristik Responden Berdasarkan Usia Berdasarkan hasil penelitian di ruang hemodialisa BRSUD Tabanan, dari 72 responden berdasarkan umur didapatkan paling banyak berusia 56-65 tahun yaitu sejumlah 25 responden $(34,7 \%)$ dan yang paling sedikit pada usia 17-25 tahun sebanyak 2 responden $(2,8 \%)$. Hasil penelitian yang dilakukan Sarastika (2019) tentang faktor-faktor yang mempengaruhi kualitas hidup pasien gagal ginjal kronik (GGK) yang menjalani terapi hemodialisa di RSU Royal Prima Medan, menunjukkan bahwa dari 70 responden, mayoritas responden berumur 55-64 tahun sebanyak 26 orang $(37,1 \%)$ dan minoritas berumur15-24 tahun sebanyak 1 orang (1,5\%). Proses degeneratif yang terjadi pada seseorang setelah usia 30 tahun akan mengakibatkan terjadinya perubahan anatomi, fisiologi dan biokimia sehingga menyebabkan penurunan kerja ginjal dan kualitas hidup 1\% setiap tahunnya (Sucahya, 2017). Pada usia 40-70 tahun, laju filtrasi glomerulus akan menurun secara progresif hingga $50 \%$ dari normal, terjadinya penurunan kemampuan tubulus ginjal untuk merebsorbsi dan pemekatan urin, penurunan kemampuan pengosongan kandung kemih dengan sempurna sehingga meningkatkan risiko infeksi dan obstruksi, dan penurunan intake cairan yang merupakan faktor risiko terjadinya kerusakan ginjal (Puspasari, 2018). 


\section{b. Karakteristik Responden Berdasarkan Jenis} Kelamin

Berdasarkan data jenis kelamin responden pada penelitian ini, di dapatkan bahwa paling banyak responden berjenis kelamin laki-laki yaitu sebanyak 41 responden $(56,9 \%)$ sementara responden perempuan sebanyak 31 responden $(41,3 \%)$. hasil penelitian ini sejalan dengan Amazihiono (2019), menyatakan mayoritas responden berjenis kelamin laki-Laki dengan persentase 20 orang $(66,7 \%)$ dan minoritas perempuan 10 orang $(33,3 \%)$. Setiap penyakit dapat menyerang manusia baik laki-laki maupun perempuan, tetapi beberapa penyakit terdapat perbedaan frekuensi antara laki-laki dan perempuan yang disebabkan perbedaan pekerjaan, kebiasaan hidup, genetika atau kondisi fisiologis. Jumlah pasien GGK laki-laki lebih banyak dari wanita kemungkinan dapat disebabkan oleh beberapa faktor. Pembesaran prostat pada laki-laki dapat menyebabkan terjadinya obstruksi dan infeksi yang dapat berkembang menjadi gagal ginjal. Selain itu, pembentukan batu renal lebih banyak diderita oleh laki-laki karena saluran kemih pada laki-laki lebih panjang sehingga pengendapan zat pembentuk batu lebih banyak daripada wanita. Laki-laki juga lebih banyak mempunyai kebiasaan atau gaya hidup yang dapat mempengaruhi kesehatan seperti merokok, mengkonsumsi kafein, alkohol, dan kurangnya olahraga yang dapat memicu terjadinya penyakit sistemik yang akan berdampak pada penurunan fungsi ginjal dan kualitas hidupnya (Kusniawati, 2018).

c. Karakteristik Responden Berdasarkan Pendidikan

Berdasarkan pendidikan dari 72 responden didapatkan bahwa paling banyak responden tingkat pendidikan SD yaitu sebanyak 31 responden $(43,1 \%)$ dan paling sedikit tidak sekolah yaitu sebanyak 4 responden $(5,6 \%)$. Hasil penelitian ini sejalan dengan penelitian Kurniawan (2019) yang menunjukan bahwa mayoritas pasien yang menjalani terapi hemodialisa di RSUD Sukoharjo berpendidikan SD sebanyak 25 orang $(55,6 \%)$. Seseorang akan memiliki tingkat keyakinan diri lebih tinggi dalam berperilaku lebih baik bila mempunyai sistem pendukung pendidikan. Tingkat pendidikan seseorang mempengaruhi perilaku sehubungan dengan peningkatan dan pemeliharaan kesehatan, perilaku pencegahan penyakit, perilaku pencarian pengobatan, dan perilaku pemulihan kesehatan serta memilih dan memutuskan tindakan atau terapi yang akan dan harus dijalani untuk mengatasi masalah kesehatannya (Kusniawati, 2018). Pasien GGK yang memiliki pendidikan lebih tinggi akan mempunyai pengetahuan lebih luas yang memungkinkan pasien dapat mengontrol dirinya dalam mengatasi masalah yang dihadapi, mempunyai rasa percaya diri yang tinggi, berpengalaman, mempunyai pemikiraan yang tepat dan mudah mengerti tentang apa yang dianjurkan oleh petugas kesehatan, serta dapat mengurangi kecemasan sehingga dapat membantu individu tersebut dalam membuat keputusan (Dani, 2015). Semakin tinggi pendidikan seseorang kesadaran untuk mencari pengobatan dan perawatan akan masalah kesehatan yang dialaminya juga semakin meningkat.

d. Karakteristik Responden Berdasarkan Status Perkawinan

Berdasarkan status perkawinan dari 72 responden didapatkan bahwa paling banyak responden yang sudah menikah yaitu sebanyak 67 responden $(93,1 \%)$ dan responden yang lajang yaitu sebanyak 5 responden $(6,9 \%)$. Hasil penelitian ini sejalan dengan penelitian yang dilakukan Kusniawati (2018) menyebutkan sebagian besar responden sudah menikah yaitu sebanyak 53 orang $(91,4 \%)$ dan yang belum menikah sebanyak 5 orang $(8,6 \%)$. Responden yang sudah menikah kemungkinan lebih besar mendapatkan dukungan yang baik dari pasangan, anak ataupun dari keluarga besarnya sehingga dengan dukungan yang baik akan meningkatkan semangat pasien dalam menjalani pengobatannya. Hal ini dapat meningkatkan rasa percaya diri, rasa optimis, dan motivasi yang dapat meningkatkan kualitas hidupnya (Kusniawati, 2018). Status pernikahan merupakan prediktor terbaik dari kualitas hidup secara keseluruhan. Hal ini bahwa individu yang menikah memiliki kualitas hidup yang lebih tinggi daripada individu yang tidak menikah, bercerai, ataupun janda/duda akibat pasangan meninggal. Karena keluarga memiliki fungsi untuk memberikan dukungan baik secara material, sosial, maupun emosional (Dewantari, 2020).

e. Karakteristik Responden Berdasarkan Pekerjaan

Berdasarkan pekerjaan dari 72 responden didapatkan bahwa paling banyak responden tidak bekerja yaitu sebanyak 51 responden $(70,8 \%)$ dan paling sedikit bekerja sebagai PNS dan swasta yaitu sebanyak 1 responden $(1,4 \%)$. Kegagalan fungsi organ pada pasien yang menjalani hemodialisa mengakibatkan terjadinya perubahan fisik berupa ketidakmampuan melakukan pekerjaan seperti sediakala dan ketergantungan terhadap orang lain akibat keterbatasan dan kelemahan fisik. Hasil yang sama juga diperoleh dalam penelitian Puspasari (2018) yang menyebutkan bahwa hampir seluruh pasien yang menjalani hemodialisa tidak berkerja lagi yaitu sebesar (86.5\%). Hal lain yang dapat mempengaruhi adalah komplikasi penyakit yang diderita pasien, menurunnya kemampuan fisik yang disebabkan oleh penyakit menjadi salah satu alasan menurunnya produktifitas pasien dalam bekerja. Pasien banyak yang tidak bekerja dan kehilangan pekerjaan akibat kondisi fisiknya yang telah menurun dan cepat lelah setiap melakukan pekerjaan yang berlebihan. Pasien GGK lebih banyak menghabiskan waktunya beristirahat di rumah dibandingkan bekerja, sehingga berdampak pada status ekonomi yang dapat mengganggu tindakan pengobatan yang dilakukan pasien (Kusniawati, 2018).

f. Karakteristik Responden Berdasarkan Lama Responden 
Lama responden mengikuti program hemodialisa dalam penelitian ini beragam. Rentang waktu menjalani hemodialisa paling banyak responden sudah $>6$ bulan yaitu sebanyak 64 responden $(88,9 \%)$ dan yang <6 bulan yaitu sebanyak 8 responden $(11,1 \%)$. Hasil penelitain ini sejalan dengan peneliain dilakukan (Rahman et al., 2016) dari 34 responden sebagian besar yang menjalani terapi hemodialisa $>6$ bulan sebanyak 22 orang $(64,7 \%)$ dan yang menjalani terapi hemodialisa $<6$ bulan sebanyak 12 orang $(35,3 \%)$. Semakin lama pasien menjalani hemodialisa maka pasien semakin patuh untuk menjalani hemodialisa karena biasanya responden telah mencapai tahap menerima ditambah mereka sudah banyak mendapatkan pendidikan kesehatan tentang penyakit dan pentingnya melaksanakan hemodialisa secara teratur (Sarastika, 2019). Pasien akan memiliki kualitas hidup yang semakin baik dari waktu ke waktu jika menjalani hemodialisa secara teratur, didukung dengan adanya perbaikan hubungan dokter ataupun perawat dengan pasien agar terbina rasa percaya pasien, karena hemodialisa bukanlah terapi untuk memperbaiki ginjal kedalam keadaan semula, tetapi merupakan terapi rehabilitatif sebagai pengganti fungsi ginjal untuk mendapatkan kualitas hidup yang lebih baik (Kusniawati, 2018).

\section{Kepatuhan Menjalani Terapi Hemodialisa}

Berdasarkan hasil penelitian di ruang hemodialisa BRSUD Tabanan dari 72 responden didapatkan bahwa paling banyak responden patuh menjalani terapi hemodialisa yaitu sebanyak 48 responden $(66,7 \%)$ dan yang tidak patuh sebanyak 24 responden $(33,3 \%)$. Hasil penelitain ini sejalan dengan peneliain dilakukan Amazihiono (2019) di Ruang Hemodialisa RSU Royal Prima Medan Tahun 2019, mayoritas responden patuh sebanyak 17 orang $(56,7 \%)$, dan minoritas tidak patuh 13 orang $(43,3 \%)$. Kepatuhan diartikan sebagai tingkatan perilaku seseorang yang mendapatkan pengobatan, mengikuti diet, dan atau melaksanakan perubahan gaya hidup sesuai dengan rekomendasi pemberi pelayanan kesehatan (Manguma, 2014). Salah satu contoh kepatuhan adalah mengikuti suatu rangkaian pengobatan di mana pasien meminum dosis obat yang sudah diresepkan pada waktu yang dianjurkan dan contoh lainnya yaitu pasien gagal ginjal kronik yang rutin menjalani terapi hemodialisa sesuai dengan anjuran dokter.

Terapi hemodialisa biasanya dilakukan seumur hidup, maka pasien akan semakin memahami pentingnya kepatuhan terhadap hemodialisa dan pasien sudah merasakan manfaatnya bila mengikuti hemodialisa dan akibatnya jika tidak melakukan hemodialisa (Puspasari, 2018). Menurut Kusniawati (2018) responden yang patuh lebih banyak dari pada yang tidak patuh. Responden yang patuh didapatkan sebanyak 37 orang $(63,8 \%)$, sedangkan responden yang tidak patuh didapatkan sebanyak 21 orang $(36,2 \%)$.
Pada pasien GGK yang menjalani hemodialisa, banyak riset menyimpulkan ketidakpatuhan meliputi empat aspek yaitu ketidakpatuhan mengikuti program hemodialisa (0\%-32,2\%), ketidakpatuhan dalam program pengobatan $(1,2 \%-81 \%)$, ketidakpatuhan terhadap restriksi cairan $(3,4 \%-74 \%)$ dan ketidakpatuhan mengikuti program diet $(1,2 \%-82,4 \%)$ (Kusniawati, 2018). Untuk dapat meningkatkan kepatuhan pasien biasanya memilki harapan dan motivasi yang tinggi agar sembuh dari penyakitnya. Pasien yang memiliki harapan dan motivasi tinggi cenderung patuh untuk melakukan hemodialisa dibandingkan dengan pasien yang memiliki harapan dan motivasi rendah. Hal ini disebabkan karena harapan dan motivasi merupakan salah satu faktor yang penting untuk meningkatkan kepatuhan, karena harapan dan motivasi itu berasal dari diri sendiri maupun dari lingkungannya (Dani, 2015). Sehingga untuk mewujudkan kepatuhan, pasien perlu menggabungkan perubahan gaya hidup dan perubahan prilaku lainnya menjadi rutinitas mereka sehari-hari.

\section{Kualitas Hidup Pasien Gagal Ginjal Kronik}

Berdasarkan penelitian di ruang hemodialisa BRSUD Tabanan dari 72 responden didapatkan bahwa paling banyak responden memiliki kualitas hidup baik yaitu sebanyak 30 responden $(41,7 \%)$ dan yang paling sedikit memiliki kualitas hidup buruk sebanyak 16 responden $(22,2 \%)$. Hasil yang sama juga di peroleh dalam penelitian Kusniawati (2018) di ruang Hemodialisa Rumah Sakit Umum Kabupaten Tangerang sebagian besar responden memiliki kualitas hidup baik sebanyak 40 orang $(69,0 \%)$, sedangkan responden yang memiliki kualitas hidup kurang sebanyak 18 orang $(31,0 \%)$.

Kualitas hidup pasien gagal ginjal kronik yang menjalani terapi hemodialisis masih merupakan masalah yang menarik perhatian para profesional kesehatan. Kualitas hidup pasien yang optimal menjadi permasalahan penting yang harus diperhatikan dalam memberikan pelayanan keperawatan yang komprehensif, dimana kualitas hidup dilihat dari 4 aspek yaitu aspek fisik, psikologi, sosial dan lingkungan (Rustandi, 2018). Terapi hemodialisa biasanya dilakukan seumur hidup, pasien menyadari bahwa terapi dialisis mengikat hidup mereka, tetapi banyaknya pembatasan dan perubahan gaya hidup yang memaksa membuat mereka sulit mematuhi rejimen terapi (Kusniawati, 2018). Terapi hemodialisa juga bisa mempengaruhi keadaan psikologi pasien. Pasien bisa mengalami gangguan proses berpikir dan konsentrasi serta gangguan dalam berhubungan sosial yang akan berdampak pada menurunnya kualitas hidup pasien.

Kualitas hidup sangat subyektif tergantung apa yang didefinisikan oleh individu itu sendiri dan berkaitan dengan pengalaman yang berarti dan bernilai bagi individu tersebut. Hal ini dikarenakan kualitas hidup merupakan suatu persepsi yang hadir dalam kemampuan, keterbatasan, gejala serta sifat 
psikososial hidup baik dalam konteks lingkungan budaya dan nilai dalam menjalankan peran dan fungsinya sebagaimana mestinya. Kualitas hidup yang rendah bagi pasien hemodialisa dapat menyebabkan perubahan pada kemampuan untuk melaksanakan atau menjalankan fungsi kehidupannya sehari-hari (Fadlilah, 2019). Menurut Black \& Hawks (2014) dijelaskan bahwa banyak aspek dari terapi pengganti ginjal yang memiliki pengaruh negatif terhadap kualitas hidup pasien dengan penyakit ginjal tahap akhir. Gagal ginjal kronik dan pengobatannya dapat mempengaruhi kualitas hidup pesien. Manajemen diri adalah penting untuk memastikan kualitas hidup yang baik bagi pesian gagal ginjal kronik.

\section{Hubungan Antara Kepatuhan Menjalani Terapi Hemodilisa Dengan Kualitas Hidup Pasien Gagal Ginjal Kronik}

Berdasarkan penelitian di ruang hemodialisa BRSUD Tabanan, didapatkan bahwa responden yang tidak patuh paling banyak memiliki kualitas hidup buruk sebanyak 12 responden $(16,7 \%)$ dan paling sedikit memiliki kualitas hidup baik sebanyak 2 responden $(2,8 \%)$, sedangkan responden yang patuh paling banyak memiliki kualitas hidup yang baik sebanyak 28 responden $(38,9 \%)$ dan paling sedikit memiliki kualitas hidup yang buruk sebanyak 4 responden $(5,6 \%)$

Hasil analisis bivariat menggunakan uji Lambda dan diperoleh nilai $\mathrm{p}=0,005$ karena nilai $\mathrm{p}<$ $\alpha(0,05)$, maka H0 ditolak. Hal ini berarti bahwa ada hubungan yang bermakna antara kepatuhan menjalani terapi hemodialisa dengan kualitas hidup pasien gagal ginjal kronik di ruang hemodialisa BRSUD Tabanan. Kuat lemahnya korelasi dilihat dari nilai $r$ yaitu 0,238 yang menunjukkan korelasi lemah antara kepatuhan menjalani terapi hemodilisa dengan kualitas hidup pasien gagal ginjal. Nilai koefisien korelasi bertanda positif ini menunjukkan bahwa semakin tinggi ketidak patuh menjalani terapi hemodialisa maka semakin besar memiliki risiko terhadap penurunan kualitas hidup psien gagal ginjal kronik di ruang hemodialisa BRSUD Tabanan dan begitu juga sebaliknya.

Hasil yang sama juga di peroleh dalam penelitian Amazihiono (2019) di Ruang Hemodialisa RSU Royal Prima Medan Tahun 2019, menunjukan bahwa ada hubungan yang bermakna antara kepatuhan menjalani terapi hemodialisa dengan kualitas hidup pasien Chronic Kidney Disease di Ruang Hemodialisa RSU Royal Prima Medan Tahun 2019 yang menjalani terapi hemodialisa dengan nilai $p$-value $=0,000 \quad(\alpha=0,05) . \quad$ Sebagian besar orang dengan penyakit kronik, kepatuhan memainkan peranan penting dalam kelangsungan hidupnya. Kepatuhan diartikan sebagai tingkatan perilaku seseorang yang mendapatkan pengobatan, mengikuti diet, dan atau melaksanakan perubahan gaya hidup sesuai dengan rekomendasi pemberi pelayanan kesehatan (Manguma, 2014). Kepatuhan pasien dalam menjalani hemodialisis baik restriksi cairan, nutrisi, konsumsi obat-obatan dan kunjungan setiap sesi hemodialisa dapat meningkatkan kualitas hidup pasien, khususnya kepatuhan dalam jadwal hemodialisa yang biasanya dilakukan 4-5 jam pengobatan dalam 2 kali seminggu (Kusniawati, 2018).

Terapi hemodialisa biasanya dilakukan seumur hidup, maka pasien akan semakin memahami pentingnya kepatuhan terhadap hemodialisa dan pasien sudah merasakan manfaatnya bila mengikuti hemodialisa dan akibatnya jika tidak melakukan hemodialisa (Puspasari, 2018). Apabila pasien tidak patuh dalam menjalani terapi hemodialisa, akan terjadi penumpukan zat-zat berbahaya dari tubuh hasil metabolisme dalam darah sehingga penderita akan merasa sakit seluruh tubuh dan jika hal tersebut dibiarkan maka akan menimbulkan kematian (Kusniawati, 2018).

Menurut Black \& Hawks (2014) dijelaskan bahwa penatalaksanaan hemodialisa tidak mengobati gagal ginjal, tetapi mungkin memperlambat perkembangan penyakit dan memiliki tujuan untuk memelihara fungsi ginjal, menunda kebutuhan transplantasi selama dapat dilakukan, meringankan manifestasi sebanyak mungkin, memperbaiki nilai kimia tubuh, dan untuk memberikan kualitas hidup yang optimal bagi pasien. Kualitas hidup sangat subyektif tergantung apa yang didefinisikan oleh individu itu sendiri dan berkaitan dengan pengalaman yang berarti dan bernilai bagi individu tersebut. Hal ini dikarenakan kualitas hidup merupakan suatu persepsi yang hadir dalam kemampuan, keterbatasan, gejala serta sifat psikososial hidup baik dalam konteks lingkungan budaya dan nilai dalam menjalankan peran dan fungsinya sebagaimana mestinya (Fadlilah, 2019). Kualitas hidup dilihat dari 4 aspek yaitu aspek fisik, psikologi, sosial dan lingkungan. Pasien yang menerima perawatan dialisis sering merasakan perasaan yang bertentangan. Mereka menyadari bahwa terapi dialisis mengikat hidup mereka, tetapi banyaknya pembatasan dan perubahan gaya hidup yang memaksa membuat mereka sulit mematuhi rejimen terapi (Kusniawati, 2018).

Hasil penelitain ini sejalan dengan penelitian dilakukan Kusniawati (2018) di ruang Hemodialisa Rumah Sakit Umum Kabupaten Tangerang, menunjukkan terdapat hubungan yang bermakna antara kepatuhan menjalani hemodialisis dengan kualitas hidup dengan nilai $p$-value $=0,019(a=0,05)$. Semakin patuh menjalani hemodialisa maka penderita gagal ginjal kronik semakin dapat beradaptasi dengan segala aktivitas-aktivitas rutin yang dijalaninya sehingga hal tersebut akan mendukung kualitas hidup pasien gagal ginjal kronik (Sarastika, 2019). Kepatuhan memainkan peranan penting bagi penderita penyakit kronik untuk mempertahankan kelangsungan hidup pasien. Untuk mencapai keberhasilan dalam pengelolaan penyakit kronik, individu harus bertanggung jawab dalam banyak aspek pengobatan mereka sendiri secara 
teratur dan jangka panjang sehingga untuk mewujudkan kepatuhan, pasien perlu menggabungkan perubahan gaya hidup dan perubahan prilaku lainnya menjadi rutinitas mereka sehari-hari (Kusniawati, 2018).

\section{KESIMPULAN}

Kepatuhan menjalani terapi hemodialisa menunjukan dari 72 responden didapatkan bahwa paling banyak responden patuh menjalani terapi hemodialisa yaitu sebanyak 48 responden dan yang tidak patuh sebanyak 24 responden.

Kualitas hidup pasien gagal ginjal kronik yang menjalani terapi hemodialisa menunjukan dari 72 responden didapatkan bahwa paling banyak responden memiliki kualitas hidup baik yaitu sebanyak 30 responden dan yang kualitas hidup buruk sebanyak 16 responden.

Terdapat hubungan antara kepatuhan menjalani terapi hemodialisa dengan kualitas hidup pasien gagal ginjal kronik di ruang hemodialisa BRSUD Tabanan dengan hasil uji Lambda diperoleh nilai $\mathrm{p}=0,005$ ( $\mathrm{p}$ $<0,05$ ) dan nilai $r$ yaitu 0,238 menunjukkan korelasi lemah.

\section{DAFTAR PUSTAKA}

1. Amazihiono, D. (2019). Hubungan antara kepatuhan menjalani terapi hemodialisa dengan kualitas hidup pasien. Jurnal Keperawatan, 9(2).

2. Aryzki, S. (2019). Pengukuran Kualitas Hidup Pasien Hemodialisis Gagal Ginjal Kronik Di RSUD Ulin Banjarmasin Menggunakan Instrumen EQ5D. Jurnal Ilmiah Ibnu Sina, 4(1), 210-224.

3. Black \& Hawks. (2014). Buku Keperawatan Medikal Bedah: Manajemen Klinis untuk Hasil yang diharapkan Edisi 8-Buku 2. Jakarta: Salemba Medika.

4. Dani, R. (2015). Hubungan Motivasi, Harapan, Dan Dukungan Petugas Kesehatan Terhadap Kepatuhan Pasien Gagal Ginjal Kronik Untuk Menjalani Hemodialisis. Jom, 2(2), 1362-1371.

5. Dewantari, P. A. (2020). Pengaruh Kenaikan Berat Badan di antara Dua Waktu Dialisis (Interdialisis Weight Gain (IDWG) terhadap Kualitas Hidup pada Pasien Gagal Ginjal Kronik yang Menjalani Terapi Hemodialisa pada Unit Hemodialisis RS PT. Arun Lhokseumawe. Kandidat: Jurnal Riset dan Inovasi Pendidikan, 2(1), 136-148.

6. Fadlilah, S. (2019). Faktor-Faktor yang Berhubungan dengan Kualitas Hidup Pasien
Hemodialisis. Jurnal Kesehatan, 10(2), 284. https://doi.org/10.26630/jk.v10i2.1454

7. Hutagaol, E. V. (2017). Peningkatan Kualitas Hidup Pada Penderita Gagal Ginjal Kronik Yang Menjalani Terapi Hemodialisa Melalui Psychological Intervention Di Unit Hemodialisa RS Royal Prima Medan Tahun 2016. Jurnal Jumantik, 2, 42-59.

8. Indonesia Renal Registry. (2018). 11th Report Of Indonesian Renal Registry 2018. 1-46.

9. Kementerian Kesehatan Republik Indonesia. (2013). Riset Kesehatan Dasar.

10. Kementerian Kesehatan Republik Indonesia. (2018). Laporan Nasional Riset Kesehatan Dasar 2018. 582.

11. Kurniawan, S. T., Andini, I. S., \& Agustin, W. R. (2019). Hubungan Self Efficacy Dengan Kualitas Hidup Pasien Gagal Ginjal Kronik Yang Menjalani Terapi Hemodialisa Di Rsud Sukoharjo. Jurnal Kesehatan Kusuma Husada, 1-7.https://doi.org/10.34035/jk.v10i1.346

12. Kusniawati. (2018). Hubungan Kepatuhan Menjalani Hemodialisis Dan Dukungan Keluarga Dengan Kualitas Hidup Pasien Gagal Ginjal Kronik Di Ruang Hemodialisa Rumah Sakit Umum Kabupaten Tanggerang. Jurnal Medikes, Vol V(Edisi II).

13. Manguma, C. dkk. (2014). Faktor-Faktor yang berhubungan dengan Kepatuhan Pasien GGK yang Menjalani Hemodialisa di BLU RSUP Prof. Dr. R. D. Kandou Manado. Universitas Sam Ratulangi.

14. National Kidney Foundation (NKF). (2016). Clinical Practice Guidelines For Chronic Kidney Disease: Evaluation, Classification and Stratification. In Annales Chirurgiae et Gynaecologiae (Vol. 90).

15. Nurlinawati, D. R. \& Y. (2019). Hubungan Tingkat Kecemasan Dengan Hemodinamik Pasien Gagal Ginjal Kronik Yang Menjalani Hemodialisa. Jurnal Ilmiah Ilmu Terapan Universitas Jambi, 3, 28-40.

16. Nursalam. (2017). Metodologi Penelitian Ilmu Keperawatan. pendekatan praktis. jakarta: salemba medika.

17. Puspasari, S. (2018). Hubungan Kepatuhan Menjalani Terapi Hemodialisa Dengan Kualitas Hidup Pasien Diunit Hemodialisa RSUD Cibabat Cimahi. Holistik Jurnal Kesehatan, 12(3), 154-159.

18. Rahman, M. T. S. A., Kaunang, T. M. D., \& Elim, C. (2016). Hubungan antara lama 
menjalani hemodialisis dengan kualitas hidup pasien yang menjalani hemodialisis di Unit Hemodialisis RSUP. Prof. Dr. R. D. Kandou Manado. Jurnal e-CliniC, 4(1), 36-40. https://doi.org/10.35790/ecl.4.1.2016.10829

19. Rustandi, H. (2018). Faktor-Faktor Yang Mempengaruhi Kualitas Hidup Pasien Chronic Kidney Disease (CKD) Yang Menjalani Hemodialisa. Jurnal Keperawatan Silampari, 1(1), $32-46$. https://doi.org/10.1017/CBO9781107415324.00 4

20. Sarastika, Y. (2019). Faktor-Faktor Yang Mempengaruhi Kualitas Hidup Pasien Gagal Ginjal Kronik (GGK) Yang Menjalani Terapi Hemodialisa Di RSU Royal Prima Medan. Jurnal Riset Hesti Medan Akper Kesdam, 4(1), 53-60.

21. Siahaan, J. V. (2018). Hubungan Antar Adekuasi Hemodialisis Dengan Kualitas Hidup Pasien Hemodialisis Di Unit HD Rumah Sakit Umum Royal Prima Medan. Jurnal Keperawatan Priority, 1(2), 16-27.
22. Sucahya, H. (2017). Hubungan Efikasi Diri Dalam Perawatan Mandiri Dengan Kualitas Hidup Pasien Penyakit Ginjal Kronik Yang Menjalani Hemodialisis Di Rsud Panembahan Senopati Bantul Yogyakarta.

23. Syamsiah, N. (2011). Faktor-Faktor Yang Berhubungan Dengan Kepatuhan Pasien CKD Yang Menjalani Hemodialisa Di RSPAU Dr Esnawan Antariksa Halim Perdana Kusuma Jakarta.

24. World Health Organization. (2015). World Health Statistics. https://doi.org/10.1590/s180998232013000400007

25. World Health Organization. (2016). Measuring Quality of Life. Diambil dari https://www.who.int/healthinfo/survey/whoqolqualityoflife/en/

26. World Health Organization. (2018). Global Status Report on Noncommunicable Disease. Diambil dari https://www.who.int/newsroom/fact-sheets/detail/noncommunicablediseases. 